\title{
Gladiaattorit pedagogiikan colosseumilla
}

\author{
Osmo Kivinen ja Pekka \\ Ristelä (2001). Totuus, \\ kieli ja käytäntö. Prag- \\ maattisia näkökulmia \\ toimintaan ja osaami- \\ seen. WSOY
}

\section{Osmo Kivinen ja Pekka}

Ristelä ovat kirjoittaneet kirjan ihmis- ja yhteiskuntatieteiden perusteista. He ovat halunneet tietää, mitä - jos mitään - annettavaa John Deweyl-lä (1859-1952) ja Richard Rortylla (1936- ) on "älyllisesti riittävän virkeille ihmisille." (s. 6) Tavoitteena on eri titeenalojen rajojen ylittäminen ja siksi kirjoittjat suosittelevat kirjaa yhtä lailla laajakatseisille tieteestä kiinnostuneille luonnontieteilijöille, kuin vaikkapa taidealan ihmisille, ammattikorkeakouluväelle ja miltei kelle tahansa.

\section{Pääasiassa kuitenkin}

liikutaan filosofisin asein pedagogiikan kentällä. Lukija saa vaikutelman siitä, miten Kivinen ja Ristelä ovat liittoutuneet suuren veden takaisiin gladiaattoriveljiin. Dewey ja Rorty kantavat raskaan vastuun selustan puolustamisessa, kun eturintaman gladiaattorit käyvät muiden muassa skolastisen tiedonkäsityksen, intellektualisminja undenoppimiskäsityksenkimppuun.

\section{Lukijan position valinta} on ratkaiseva ja samalla vaikea. Pitäisikö asettua katselemaan gladiaattorien taistelua ja nauttia siitä, miten Kivisen ja Ristelän pragmaatikot pistävät vastustajan kumoon keinoja kaihtamatta vai mennäkö mu- kaan taisteluun puolelle tai toiselle? Vai tulisiko peräti asettua keisarin rooliin nostamaan peukaloa pystyyn taistelun lopussa? Ja kenelle kansa mahtaisi huutaa huraansa: keisarille, pragmaatikko-gladiaattoreille vai peräti alakynteen ahdistetuille kartesiolaisille?

Kivinen ja Risteleä tuovat ansiokkaasti esiin Deweylle tyypillisen ja Rortyn täsmentämän argumentaation representionalismiksi kutsuttua ajattelutapaa vastaan. Rortyn mukaan meidän tulisi luopua näkemisen metaforaan perustuvasta tavasta jäsentää tiedon ja sen kohteen suhde. Ihmisen mieli ei ole kuin sisäinen silmä, peili tai vastaanotin, johon heijastuu kuva ulkomaailman olioiden todellisesta luonteesta. Rortyn mukaan tieto on ennen kaikkea väline maailmassa selviämiseen ja ongelmien ratkaisemiseen, ei niinkään maailman esittämiseen. Kun muutamme käsityksemme tiedon luonteesta, samalla meidän käsityksemme tiedon arvioinnista muuttuu. Tiedon arvioinnin kriteerinä ei enää ole sen vastaavuus todellisuuden kanssa, vaan sen on perustuttava tavalla tai toisella tiedon käyttökelpoisuuteen. Näin siis tiedossa ei ole kysymys siitä, miten kuvata todellisuus oikein, vaan siitä, miten hankkia toimintatavat, joilla tulla toimeen todellisuudessa, ympäristön, itsensä ja muiden ihmisten kanssa.

\section{Toinen Kivisen ja}

Ristelän kritisoima dualismi on tekemisen ja ajattelun vastakkainasettelu. Tavoitteena tulisi Deweyn mukaan olla ajatteluun liittyvän mystiikan poistaminen ja ajattelun ymmärtäminen osana ihmisen toiminnan kokonaisuutta. Kirjassa on hyvin kiinnostavasti esitetty ajatuskulku siitä, miten ajattelu on eräänlaista siirrettyä toimintaa. Sen sijaan, että ryhdyttäisiin "tekemään asialle jotakin", keskitystään ottamaan selvää esteistä ja voimavaroista ja suunnittelemaan myöhemmin suoritettavia toimenpiteitä.

\section{Deweyn ja Rortyn}

esittämät ajatukset ovat merkittäviä, mutta ongelmalliseksi Kivelän ja Ristelän tarkastelun tekee se, että keskustelua tiedon luonteesta filosofiassa on käyty jo hyvin pitkään. Kivisen ja Ristelän esityksestä saa sen kuvan, että taistelua olisi käyty vain yhdellä rintamalla, kartesiolaiset vastaan pragmatistit. Kuitenkin kartesiolaisuuden kritiikki on koko postkantilaisen filosofian luonteenomainen piirre. 1900-luvun filosofiassa niinkin erilaisilta vaikuttavat filosofit kuin Ludwig Wittgenstein (1889-1951) ja Martin Heidegger (1889-1976) ovat tuottaneet merkittäviä ajatuksia, joista pragmaattinen manerismi on kaukana. Olisi mielenkiintoista tarkastella hieman tarkemminkin heidän ajatteluaan ennen kiirehtimistä pedagogiikan alueelle. Tämä ei ole kuitenkaan Kivelän ja Ristelän kirjan tematiikkaa, vaan he pyrkivät avaamaan uusia rintamia pedagogiseen keskusteluun. 
Kirjoittajat väittävät, että sivustakatsoja ei opi. "Sivustakatsoja" on kovin hyvin visuaalinen termi, joten argumentaation rakentaminen sen varaan johtaa helposti kuvaan, jossa tekeminen ja toiminta ymmärretään kovin kapeasti.

Toiminnan käsite voidaan ajatella laajaksi yläkäsitteeksi, jonka elementteinä on tekoja, jotka puolestaan koostuvat yksittäisistä operaatioista. Näin myös ajattelu on toimintaa, ja ongelmaksi asettuu sen määrittäminen, mitkä ovat ajattelutoiminnan spesifit piirteet. Kivinen ja Ristelä kirjoittavat:

Deweynmukaanoppilaidentiedonhankintaymmärretäänliianusein kummallisena "teoreettisena" sivustakatsomisena, toiminnastairrallisena älynkäytäntönä,jolla eioleyhteyttä rnumiilliseen toimintaan. Tällöintekemisenjasen seurauksienvälinen yhteys rikotaan,jollointoisaallejää toiminnanmerkityksetönruamiillinen osums, toisaalletaasjokinerityisen toiminnan "merkitys", jonkauskotaan olevantavoitettavissapuhtaan "henkisesti”. (s. 149)

\section{Kirjoittajat nimeävät} tämän virheellisen näkemyksen "skolastiseksi tiedonkäsitykseksi”. Tämän vuoksi ei ymmärretä, että kasvatuksen sisällössä on aina kyse ruumiin käyttöäjamateriaalienkäsittelyä edellyttävästätekemisestä(s. 149). Seurauksena tästäopetuksen sisällöstätuleeoppijantarpeistaja tavoitteista eristettyä,jotain sellaista,joka onvainopeteltavaulkoajatarvittaessa toistettava. (s. 149) Kivisen ja Ristelän edustaman pragmatistisen näkemyksen mukaisesti lähdettäisiin ainaliikkeelletilanteista,jotkapitävätsisällään tekemällä oppimista, vaihtoehtojen kokeiluaja uuden tuottamista (s. 149).

\section{Kirjoittajat ovat}

mielestäni oikeilla jäljillä, mutta heittävät johtopäätöksissään niin sanotusti lapsen pesuveden mukana. Henkisen ja ruumiillisen työn eroaminen on yksi länsimaisen kulttuurin synnyn lähtökohdista.

Tunnetustihan orjatyövoiman käyttö perustui siihen, että yksittäisen ihmisen on mahdollista tuottaa enemmän kuin hänen omaan kulutukseensa välttämättömästi kuluu. Tämä mahdollisti työn ja vapaa-ajan erottamisen. Muinaisessa Kreikassa tuota vapaaaikaa kutsuttiin skholeksi, kouluksi. Koulu siis merkitsee vapaa-aikaa, aikaa, joka on vapautettu välttämättömästä työprosessista. Tämän prosessin uskonnollisena ja filosofisena ilmaisuna voidaan pitää erottelua ruumiin ja sielun tai hengen välillä. Mutta on kovin outoa, jos sekoitamme käsitteelliset erottelut reaalisista. Toki on niin, että länsimaissa myös henkinen ja ruumiillinen työ ovat erottuneet, mutta en jaksa uskoa, että sekoittamalla ne uudelleen käsitteellisesti voisimme reaalimaailmassa palata niiden "alkuperäiseen yhteyteen."

\section{Väite, jonka mukaan} lähdettäisiin aina liikkeelletilanteista,jotkapitävätsisällääntekemällä oppimista, on mielestäni aivan yhtä yksipuolinen, kun vastakkainen väite, jonka mukaan pitäisi välttää tekemällä oppimista. Niin kutsuttu Kolbin kehä ei ole ehkä uusin, eikä välttämättä teoreettisesti sofistikoituneinkaan esitys oppimisprosessin eri puolista ja oppijoiden oppimisen erilaisista lähtökohdista, mutta sen avulla voi hyvin jäsentää oppimisen kontekstisidonnaisuutta (aivan kuten pragma- tistisesta filosofiasta lähtökohdasta tulisi oivaltaa). Ei siis ole aina lähdettävä jostakin lähtökohdasta, vaan on lähdettävä tarvittaessa jostakin tietystä lähtökohdasta, joka riippuu oppimisen kohteesta, oppijasta ja oppimistilanteesta. Tekstissä olisi ollut hyvä erottaa historiallisen kehitysprosessin kuvaus aktuaalisesta oppimistilanteesta ja tehdä ero ilmiön genesiksen ja pätevyyden välille. Oppijan ei tarvitse käydä samaa historiallista priosessia läpi, kuin mitä sen ilmiön synty ihmiskunnan historiassa on edellyttänyt. Selvimmin tämä ilmenee matematiikan ja logiikan opiskelussa ja opetusmenetelmissä. Voi olla didaktisesti perusteltua opiskella myös näiden tieteenalojen historiaa, mutta oppiminen niissä tapahtuu pääasiallisesti "epähistoriallisesti” ja niissä argumentaation pätevyyttä ei varmisteta historiallisella aineistolla. Kivinen ja Ristelä ovat toki rajanneet tarkastelunsa ihmis- ja yhteiskuntatieteisiin, mutta tekstissä on hyvin vahvoja oppimisteoreettisia yleistyksiä, joita ei erikseen ole spesifioitu koskemaan historiallisia tietämyksen aloja.

\section{Kivinen ja Ristelä}

väittävät, että tasoerottelua ei ajattelussa tarvita (s. 161). Väite ja sen argumentointi on hyvin linjassa kirjan kokonaisnäkemyksen kanssa, mutta juuri tässä en ole vakuuttunut tämän ajattelutavan hedelmällisyydestä. Ajattelun tehtävänä on mielestäni juuri tuottaa erotteluja ja myös laadullisia jaotteluja ja hierarkioita, joiden perustat ovat toki relationaalisia. Jos hyväksymme väitteen, menetämme käsittääkseni arvokkaan mahdollisuuden 
ymmärtää ajattelun ja käytännön välisen suhteen jännitteisen prosessin jäsentyneesti.

\section{Esimerkkinä otan meta-}

kognition käsitteestä esitetyn kritiikin, jonka avuksi on esitetty Gilbert Rylen introspektrioon kohdistama kritiikki. Se soveltuu kirjoittajien mukaan lähes sellaisenaan metakognition käsitteen kyseenalaistamiseen (163-164).

Rylen argumentti etenee seuraavasti: Olettakaamme, että mielessämme tosiaan toimii meta-kognitiivinen prosessi, jolla on tietoa kognitiivisen tason toiminnasta. Tämän prosessin olettaminen selittää introspektiivisen, välittömästi havaitun oman mielen toimintaa koskevan tiedon mahdollisuuden. Tämä metakognitiivisen tason olemassaolo ei kuitenkaan ole ulkopuolisen tarkkailijan havainnoitavissa, ja siksi sitä koskevan tiedon pitää myös olla introspektiivista. Meidän on siis välttämätöntä olettaa kolmas taso, joka tarkkailee toista tasoa. Tästä ei kuitenkaan ole apua, koska myös tämä taso on havaittavissa vain introspektiivisesti, ja näin tarvitsemme yhä uusia metatasoja. Näin pitäisi jatkaa loputtomiin tai vaihtoehtoisesti rajoittaa tasojen määrä mielivaltaisesti. Näin emme olisi selittäneet mitään.

\section{Rylen argumentti ei}

kuitenkaan ole kovin vakuuttava. Metakognition ideahan on siinä, että kiivetään ikään kuin portaita pitkin ylemmälle tasolle ja katsotaan alas. Mikään ei estä palaamasta portaita takaisin. Eikä myöskään ole mahdotonta pysähtyä jollekin tasolle ja nähdä vielä portai- kon jatkuvan. Voidaan myös ajatella, että tikkaat heitetään pois, kun ollaan päästy halutulle tasolle. Käsittääkseni Rylen kritiikki liittyi todellakin psykologian metodologiseen keskusteluun ja introspektion pätevyyteen. En näe sen yhteyttä siihen teoriaan, jossa pyritään selvittämään taitavan oppimisen rakenteita metakognition käsitettä hyväksikäyttäen. Jos oikein ymmärrän pragmatistitkin suosivat käsitteiden instrumentaalista tulkintaa pikemminkin kuin ajatusta siitä, että yksittäisellä käsitteellä tulisi olla reaalinen kohde. Käsitteet ovat todellisuuden jäsentämisen ajatuksellisia muotoja. Käsiteellistä järjestelmää rikastuttamalla saamme jäsentyneen käsityksen todellisuudesta ja samalla itse todellisuus jää aina käsitteidemme ulottumattomiin. Todellisuuden voi näin jättää silleen.

\section{Kivinen ja Ristelä}

väittävät, että oman oppimisen itsetarkoitukselliseen tutkailuun kannustavat käytännöt voidaan pohjimmiltaan nähdä vain koulun toimintaa perinteisesti hallinneen testaamisen käytännön henkeä vastaavana uudelleenoikeuttamisena. (165-166) He vetoavat Deweyn oppeihin sanoessaan, että oppimista tapahtuu parhaiten silloin, kun oppilaat eivät tiedosta opiskelevansa. On hyvä, että vallitsevia ns. uusia oppimisajatuksia ravistellaan, mutta jälleen tuntuu, että se tehdään vain menemällä toiseen äärimmäisyyteen. Kuka on vaatinut itsetarkoituksellisesti tarkkailemaan oppimista tai yleensäkään on esittänyt, että itsetarkkailusta tulisi oppimisen päämäärä?
Reflektiivinen suhde oppimiseen ja tekemiseen nyt vain näyttää olevan taitavan toiminnan yksi piirre. En näe mitään syytä yrittää heikentää pyrkimystä tietoisesti tarkastella niitä ehtoja, joiden puitteissa oppija oppii. Tässäkin tietysti on otettava huomioon oppijoiden ajattelun kehittyneisyys ja opittavan asian luonne.

\section{Totuus, kieli ja käytäntö} -kirja on monilta osin poleeminen. Taistelu kirjassa on niin tuimaa, että iskut tuntuvat osuvan usein ohi, joskus ne osuvat ja joskus ne tuntuvat osuvan myös gladiaattorien omaan nilkkaan. Ehkä on siis sittenkin viisainta pysyä sivustakatsojana, silläkin uhalla, ettei teoksesta mitään oppisikaan ja pidättäytyä lopullisesta tuomiosta. Taistelukentillä olijat ovat jo tuomittuja - vain aniharva gladiaattoriksi alistettu kykenee vapauttamaan itsensä ja nauttimaan vapaan miehen elämästä.

Teoksesta saa sen kuvan, että (elämässä) ei ole kuin yksi suuri näyttämö, toiminnan kenttä, jossa me kaikki olemme varustautuneina samoin asein. Kuitenkin erilaisten roolien omaksuminen, ajattelun eri tasoilla liikkuminen, pinta- ja syvyysulottuvuuden löytäminen ovat keskeisiä ulottuvuuksia, joilla niin pragmaatikot kuin muutkin "gladiaattorit" haluaisivat liikkua.

\section{Oikeille gladiaattoreille} tällaisen refleksiivisen oppimisen mahdollisuutta ei juuri suotu. Heidän oli keskityttävä toimintaan ja tekemiseen henkensä säilyttämiseksi. 
Nykyisen ajan suuria tavoitteita on saada itse valita roolinsa, tapansa oppia ja myös oikeus ottaa osaa haluamaansa yhteisöön. Tämä ei voi toteutua puhtaana vapauden valtakuntana, vaan aina säilyy välttämättömyyden val- takunta, työn valtakunta. Mutta vasta tuon valtakunnan tuolla puolen alkaa inhimillisten voimien tosi kehitys tieteen, taiteen, kasvun ja kehityksen valtakunta. Gladiaattorien taistelun seuraaminen voi olla katsojan ilo, mutta sa- malla elää toivo siitä, että gladiaattorit yhdistävät voimansa, vapauttavat itsensä ja ryhtyvät kuka mihinkin hyödylliseen puuhaan.

Pekka Kalli 